\title{
REVIEW
}

\section{Zooxanthellae that open calcium channels: implications for reef corals}

\author{
Ted A. McConnaughey* \\ 2906 Norman Dr., Boise, Idaho 83704, USA
}

\begin{abstract}
Toxins that open cell membrane calcium channels have been found in the dinoflagellate genus Symbiodinium, and likely occur in most zooxanthellae. I used published observations to examine some potentially far-reaching consequences to reef corals. Algal toxins may stimulate coral calcification by opening $\mathrm{Ca}^{2+}$ channels on the calcifying ectoderm. The coral discharges the resulting protons $\left(\mathrm{Ca}^{2+}+\mathrm{HCO}_{3}{ }^{-} \rightarrow \mathrm{CaCO}_{3}+\mathrm{H}^{+}\right)$into its coelenteron cavity, where they improve algal bicarbonate and nutrient assimilation. Coupling calcification with autotrophic physiologies contributes to the success of highly calcareous zooxanthellar symbioses, and to their associations with nutrient-poor tropical waters. Nutrient shortages freeze zooxanthellae in the G1 phase of the cell cycle. Dinoflagellates are often most toxic at such times, perhaps because toxins modulate their nuclear mix of cations, to control DNA conformation and activity. Increased $\mathrm{Ca}^{2+}$ influx into host cells disrupts cell adhesion and induces apoptosis. Zooxanthellae assimilate host nutrients, complete G1, divide, and disperse to new hosts. Nutrient shortages associate with high sea surface temperatures (SST), producing correlations between SST, calcification, and algal exit. Zooxanthellae proliferate when nutrients are abundant, but when nutrients later disappear, usually as SST warms, toxins and the departure of over-abundant zooxanthellae potentially overwhelm the coral and cause coral bleaching.
\end{abstract}

KEY WORDS: Toxin · Coral · Polyketide · Symbiodinium - Calcification · Photosynthesis · Bleaching Resale or republication not permitted without written consent of the publisher

\section{INTRODUCTION}

Several 'bioactive compounds' or 'toxins' that open membrane $\mathrm{Ca}^{2+}$ channels have been discovered in the dinoflagellate genus Symbiodinium. A given strain of algae may produce several structurally related toxins. Zooxanthellatoxins $\mathrm{A}$ and $\mathrm{B}\left(\mathrm{A}: \mathrm{C}_{140} \mathrm{H}_{232}\right.$ $\left.\mathrm{O}_{57} \mathrm{NS}\right)$ and symbiodinolide $\left(\mathrm{C}_{137} \mathrm{H}_{232} \mathrm{O}_{57} \mathrm{NS}\right)$ were found in zooxanthellae strain Y-6, likely clade A2, from the acoel flatworm Amphiscolops (Nakamura et al. 1993, Kita et al. 2007). Clade A1 algae from a Hawaiian tidepool make zooxanthellamides C1-5 $\left(\mathrm{C}_{128} \mathrm{H}_{220} \mathrm{O}_{53} \mathrm{~N}_{2} \mathrm{~S}_{2 i}\right.$ Onodera et al. 2005). Zooxanthellamide-D $\left(\mathrm{C}_{54} \mathrm{H}_{83} \mathrm{O}_{19} \mathrm{~N}\right)$ occurs in clade $\mathrm{B}$ algae from the jellyfish Cassiopeia (Fukatsu et al. 2007). Although the first of these toxins were discovered nearly 20 yr ago, little is known about how zooxanthellae use them. This article provides a roadmap for experiments.

Most of these alcohol-soluble polyketides consist of long continuous looped carbon chains, about $9 \mathrm{~nm}$ long, decorated with alcohols and ketones, plus bisepoxides in the zooxanthellatoxins and symbiodinolide. Zooxanthellatoxins $\mathrm{A}$ and $\mathrm{B}$ contract mammalian muscle tissues at $0.7 \mu \mathrm{M}$ (Nakamura et al. 1993), and symbiodinolide opens mammalian N-type $\mathrm{Ca}^{2+}$ channels at $7 \mathrm{nM}$ and immediately ruptures host cells at $2.5 \mu \mathrm{M}$ (Kita et al. 2007). Symbiodinium toxins 
are, however, much weaker than the $\mathrm{Ca}^{2+}$ influx agonist maitotoxin, which may be the most potent dinoflagellate toxin.

Coral symbionts have not yet been examined for toxins, but all analyzed strains of Symbiodinium apparently make $\mathrm{Ca}^{2+}$ channel openers, so coral symbionts likely do also. Symbiodinium furthermore retains the specialized machinery for making elaborate polyketides despite being a small dinoflagellate with the smallest known dinoflagellate genome (LaJeunesse et al. 2005).

Algal toxins appear abundant enough to affect the host coral. Cultured zooxanthellae strain Y-6 contains 75 and $40 \mu \mathrm{M}$ of zooxanthellatoxins A and B, plus $76 \mu \mathrm{M}$ symbiodinolide (Nakamura et al. 1993, Kita et al. 2007). These values may not be maxima, due to incomplete yield on toxin extractions, and variable toxin levels in the algae. Symbiodinium can occupy most of the volume of infected cells and reaches densities of millions of cells $\mathrm{cm}^{-2}$ in the coral endoderm.

$\mathrm{Ca}^{2+}$ channel openers can be potent physiological modulators. Eukaryotic cells maintain sub-micromolar levels of cytosolic free $\mathrm{Ca}^{2+}$. Small increases in intracellular $\mathrm{Ca}^{2+}$ affect many cellular functions, in- cluding motility, secretion, exocytosis, transcription, cell adhesion, apoptosis, dehydrogenation reactions, and immunological responses including the generation of reactive oxygen species (ROS) and nitric oxide (NO; Clapham 2007). Intracellular parasites and symbionts often hijack the regulation of host cell $\mathrm{Ca}^{2+}$, and Symbiodinium may do likewise (Fang et al. 1998, Sawyer \& Muscatine 2001, DeSalvo et al. 2008, Kita et al. 2010, Yuyama et al. 2011). $\mathrm{Ca}^{2+}$ channel openers provide a mechanism. Algal colonization presumably succeeds best in hosts with compatible physiologies, especially if toxins suppress harmful host physiologies or stimulate beneficial ones.

Many of Symbiodinium's prominent hosts are highly calcareous, including foraminifera, sponges, giant clams, and corals. Symbiotic corals generally calcify faster than non-symbiotic corals, especially during the daytime (e.g. Gattuso et al. 1999). Opening $\mathrm{Ca}^{2+}$ channels on the coral's calcifying ectoderm would stimulate calcification more directly than feeding the coral and raising $\mathrm{pH}$ and $\mathrm{O}_{2}$ levels. Calcification generates protons $\left(\mathrm{Ca}^{2+}+\mathrm{HCO}_{3}{ }^{-} \rightarrow \mathrm{CaCO}_{3}+\mathrm{H}^{+}\right)$ which the coral discharges into its semi-enclosed coelenteron cavity. That potentially improves algal $\mathrm{HCO}_{3}{ }^{-}$and nutrient uptake (Fig. 1). The following

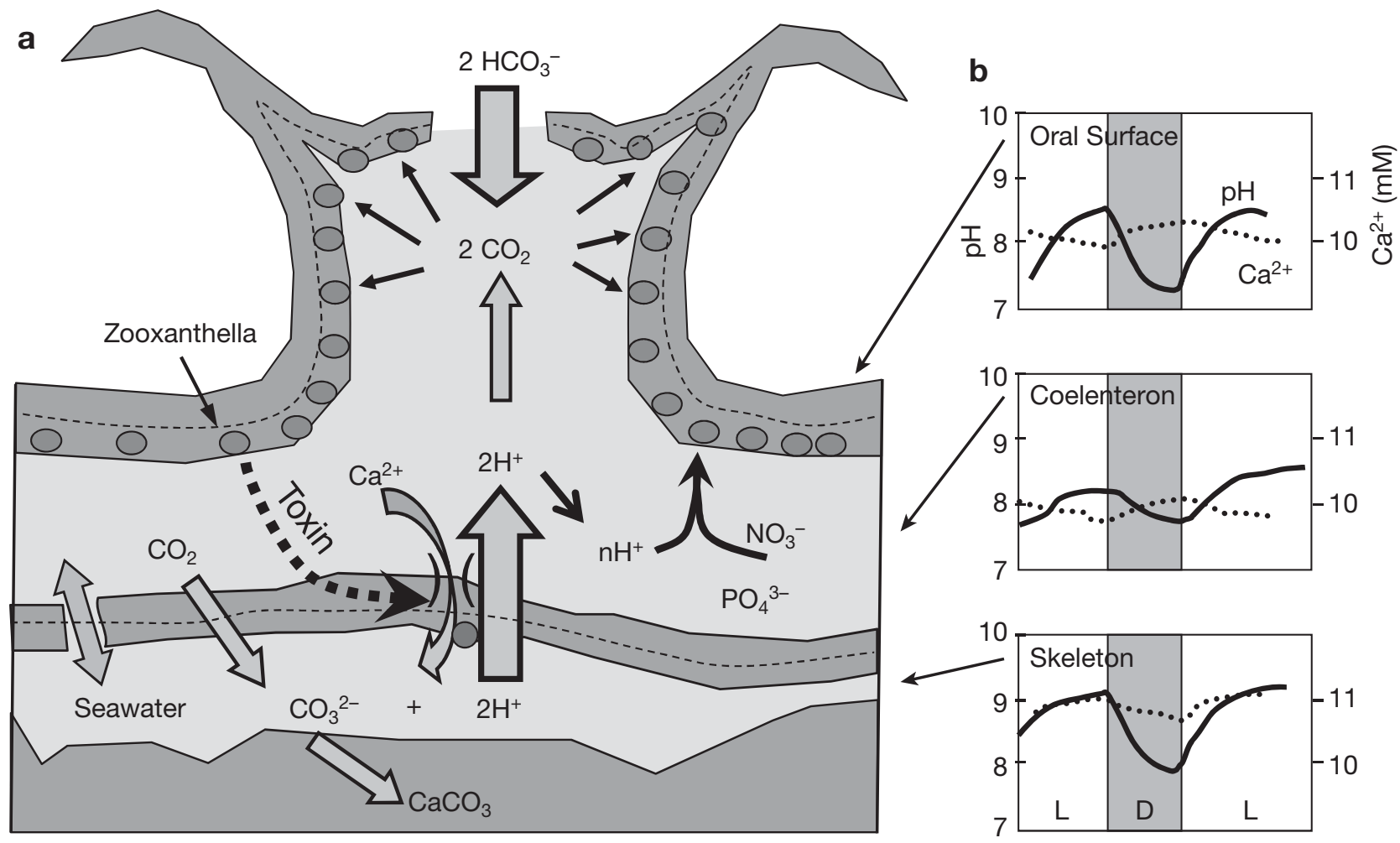

Fig. 1. Coral physiological model. (a) Coral calcification generates protons, which the coral discharges into its coelenteron cavity. Zooxanthellae inhabit adjacent cells of the oral endoderm, and potentially benefit from improved $\mathrm{CO}_{2}$ and nutrient uptake resulting from this proton discharge. (b) $\mathrm{pH}$ and $\mathrm{Ca}^{2+}$ measured above the coral, in the coelenteron, and at the calcification site, in light

(L) and dark (D), based on Al-Horani et al. (2003a,b). Ries (2011) reported pH values exceeding 10 at the calcification site 
sections explore these ideas. Later sections explore how algal toxins may contribute to algal dispersal, coral bleaching, and algal cell cycles.

\section{CALCIFICATION AND PHOTOSYNTHESIS}

Corals bring seawater into the calcification site (Bentov et al. 2009, Tambutté et al. 2012), and apparently raise its $\left[\mathrm{Ca}^{2+}\right]$ and $\mathrm{pH}$ through $\mathrm{Ca}^{2+} / 2 \mathrm{H}^{+}$exchange pumping by $\mathrm{Ca}^{2+}$ ATPase (Niggli et al. 1982, Dixon \& Haynes 1989). $\left[\mathrm{Ca}^{2+}\right]$ increases $<10 \%$, while $\mathrm{pH}$ rises 1 to $2 \mathrm{pH}$ units (Al-Horani et al. 2003a,b, Ries 2011; Fig. 1b bottom panel). $\mathrm{CO}_{2}$ diffuses into this alkaline fluid and reacts to produce $\mathrm{CO}_{3}=$ (McConnaughey 1989, 2003). This raises the $\left[\mathrm{Ca}^{2+}\right]$ $\left[\mathrm{CO}_{3}{ }^{2-}\right]$ ion product and speeds calcification (Cohen \& McConnaughey 2003).

Corals have abundant $\mathrm{Ca}^{2+}$ channels (Zoccola et al. 1999), which probably concentrate on the coral's calcifying ectoderm, along with $\mathrm{Ca}^{2+}$ ATPase (Zoccola et al. 2004). This localization of $\mathrm{Ca}^{2+}$ channels may allow zooxanthellae to selectively stimulate coral calcification.

The coral discharges the protons from calcification into its coelenteron cavity. There they react with $\mathrm{HCO}_{3}{ }^{-}$to produce $\mathrm{CO}_{2}$, which is captured by zooxanthellae in the surrounding endoderm (Fig. 1a). $\mathrm{CO}_{2}$ levels below ambient $(\sim 10 \mu \mathrm{M})$ strongly inhibit photosynthesis in freshly isolated zooxanthellae (Leggat et al. 2002; Fig. 2a). High coral photosynthetic rates and mild coelenteron $\mathrm{pH}$ values (Al-Horani et al. 2003a,b; Fig. 1b, middle panel) suggest that the protons from calcification largely counteract photosynthetic alkalinization and $\mathrm{CO}_{2}$ depletion.

Fig. 2b estimates how calcification and photosynthesis affect seawater $\mathrm{CO}_{2}$ and pH. Fig. 2c estimates carboxylation efficiency (\% Vmax), based on kinetics in Fig. 2a. The shaded diagonal arrows depict a 1.3 ratio of calcification to net photosynthesis (C:P). This was the average for several corals examined by Gattuso et al. (1999), and for corals not supplemented with nutrients by Tanaka et al. (2007; see Fig. 4c). Photosynthetic removal of $30 \%$ of the dissolved inorganic carbon (DIC) without calcification raises $\mathrm{pH}$ from 8.0 to 8.8 , reduces $\mathrm{CO}_{2}$ from 10 to $1 \mu \mathrm{M}$, and reduces carboxylation efficiency to $8 \% \mathrm{Vmax}$. Yet the same amount of photosynthesis at $\mathrm{C}: \mathrm{P}=1.3$ reduces $\mathrm{CO}_{2}$ only to $5 \mu \mathrm{M}$, and carboxylation efficiency to $30 \%$ Vmax. In this extreme example, calcification triples photosynthetic efficiency.

Coral calcification is generally considered a weak photosynthetic stimulus (Tanaka et al. 2007). Most experiments minimize $\mathrm{CO}_{2}$ stress, however, and that minimizes the stimulus. Gattuso et al. (2000) also showed that reduced-Ca $\mathrm{Ca}^{2+}$ seawater prevents net calcification without inhibiting photosynthesis. These experiments probably did not stop the proton transport into the coelenteron. Finally, branching and foliose corals calcify fastest in their apical polyps, and
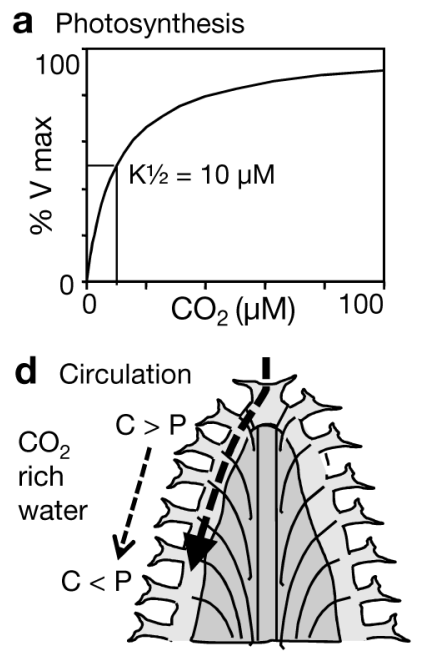

b $\mathrm{pH}$ and $\mathrm{CO}_{2}$

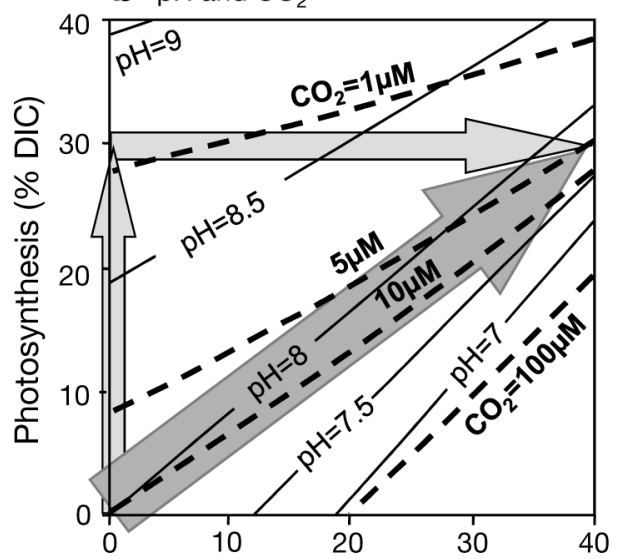

C Carboxylation efficiency

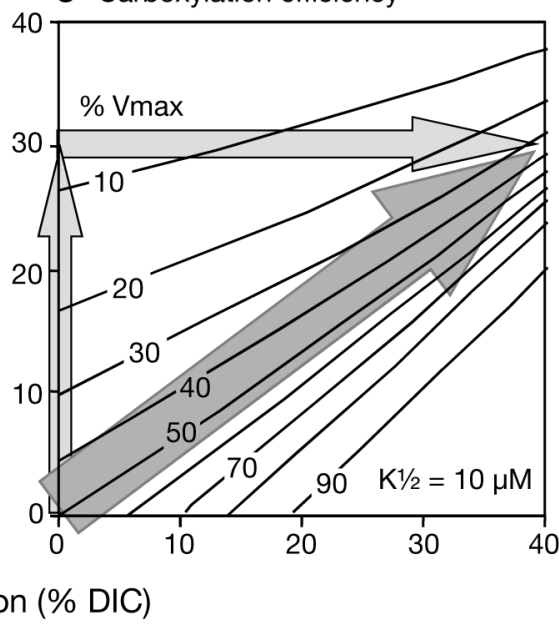

Fig. 2. Photosynthesis, calcification, and $\mathrm{CO}_{2}$. (a) Photosynthetic kinetics of freshly isolated zooxanthellae (Leggat et al. 2002). Photosynthesis is half saturated at $\sim 10 \mu \mathrm{M} \mathrm{CO}_{2}$, which is close to ambient $\mathrm{CO}_{2}$ levels. (b) $\mathrm{pH}$ (solid lines) and $\mathrm{CO}_{2}$ (heavy dashed lines) in warm seawater, subject to calcification and photosynthesis ( $x$ - and $y$-axes, as \% of total dissolved inorganic carbon, DIC). Shaded diagonal arrow depicts 1.3 ratio of calcification to photosynthesis. Seawater initially contains $10 \mu \mathrm{M} \mathrm{CO}_{2}$ at $\mathrm{pH}$ 8. (c) Carboxylation efficiency (\% Vmax), calculated from $\mathrm{CO}_{2}$ levels from (a), and photosynthetic kinetics of Leggat et al. (2002). (d) Coelenteron water circulation hypothesized for branching coral, which brings $\mathrm{CO}_{2}$-rich water from rapidly calcifying branch tips to photosynthetic later polyps, $\mathrm{C}=$ Calcification, $\mathrm{P}=$ Photosynthesis 
photosynthesize mainly in their lateral polyps (Fang et al. 1989). For calcification to stimulate photosynthesis, the coral would need to transport $\mathrm{CO}_{2}$-rich water from the apical to the lateral polyps. In support of this idea, Gladfelter (1983) detected inward ciliary currents at the branch tips of Acropora (Fig. 2d).

Summarizing, coral calcification likely stimulates photosynthesis when $\mathrm{CO}_{2}$ is depleted, as might occur under stagnant conditions, with massive and encrusting morphologies, and when non-calcareous algae lower ambient $\mathrm{CO}_{2}$ levels. Calcification may also improve photosynthesis in dim light, judging from the prevalence of calcification among deep-living algae (Aponte \& Ballantine 2001).

\section{NUTRIENT UPTAKE}

Corals inhabit some of the earth's most oligotrophic environments (Fig. 3a). Thermal stratification impedes nutrient inputs to surface waters, so nutrients correlate negatively with temperature (Fig. 3b,c). Turbulence and thermocline shoaling bring nutrients to the surface and promote the growth of zooxanthel- lae. Conversely, sunny, warm, calm conditions stratify the water column and intensify surface nutrient depletion.

Nutrient scarcity often accelerates calcification. Corals calcify faster at high sea surface temperatures (McNeil et al. 2004, Silverman et al. 2006, Cooper et al. 2012), when nutrients are generally depleted. Corals also calcify faster without nutrient supplements (Fig. 4) (Kinsey \& Davies 1979, Marubini \& Davies 1996, Marubini \& Thake 1999, Ferrier-Pagès et al. 2000, 2001, Renegar \& Riegl 2005, Holcomb et al. 2010). Even in contrary examples (Tanaka et al. 2007), nutrient supplements increase photosynthesis and biomass more than calcification. Relative to photosynthesis and biomass, nutrient shortages induce faster calcification (Fig. 4c).

Connections between calcification and nutrient uptake are also apparent in various plants. Calcareous reef algae show enhanced phosphate uptake (Demes et al. 2010). Coccolithophorids often dominate the summertime plankton, when nutrients are depleted, and calcify faster when nutrients are scarce (Paasche \& Brubak 1994). Calcareous plants dominate in oligotrophic alkaline, $\mathrm{Ca}^{2+}$-rich lakes (McConnaughey

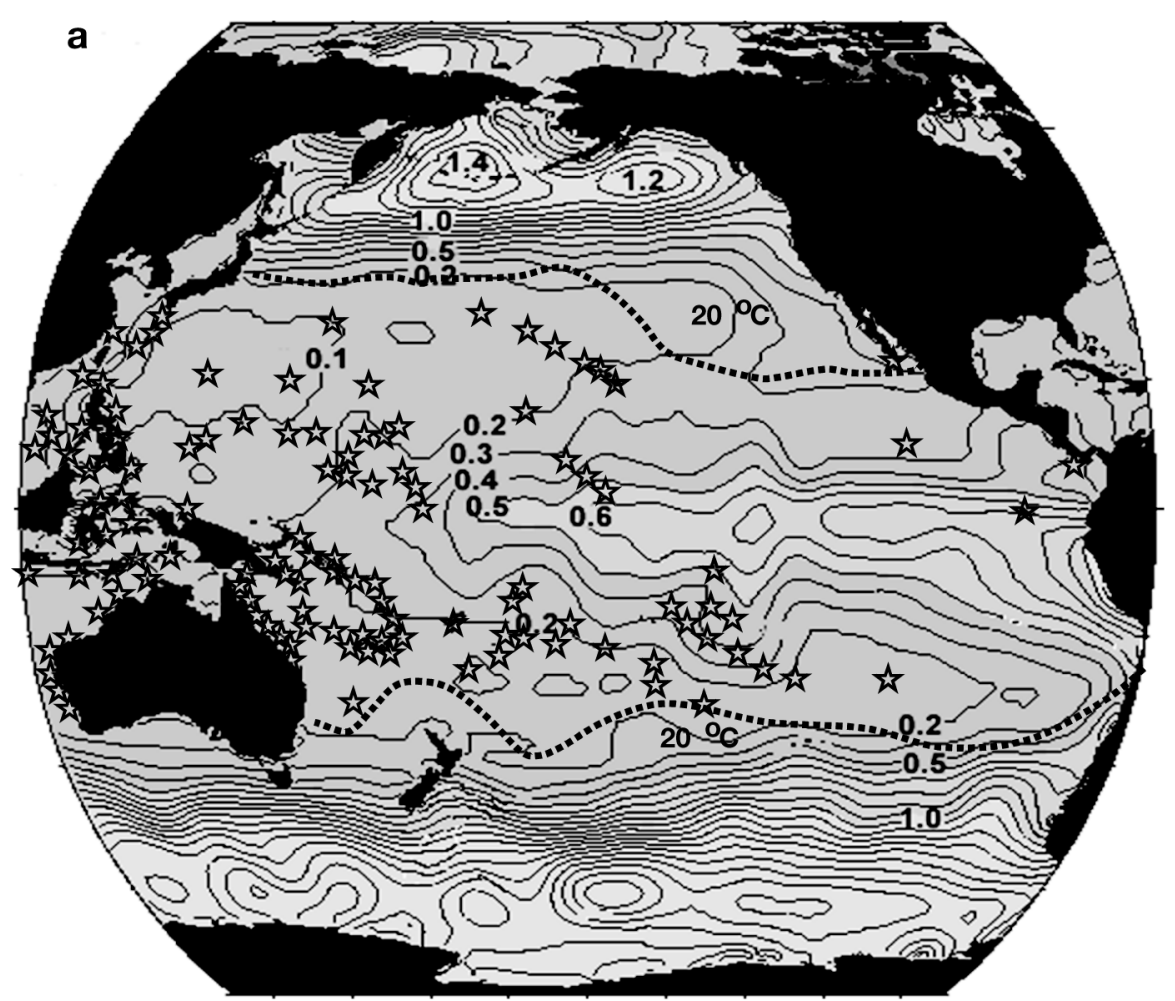

b Temperature $\left({ }^{\circ} \mathrm{C}\right) ; \mathrm{N}, \mathrm{P}\left(\mu \mathrm{M} \mathrm{kg}{ }^{-1}\right)$
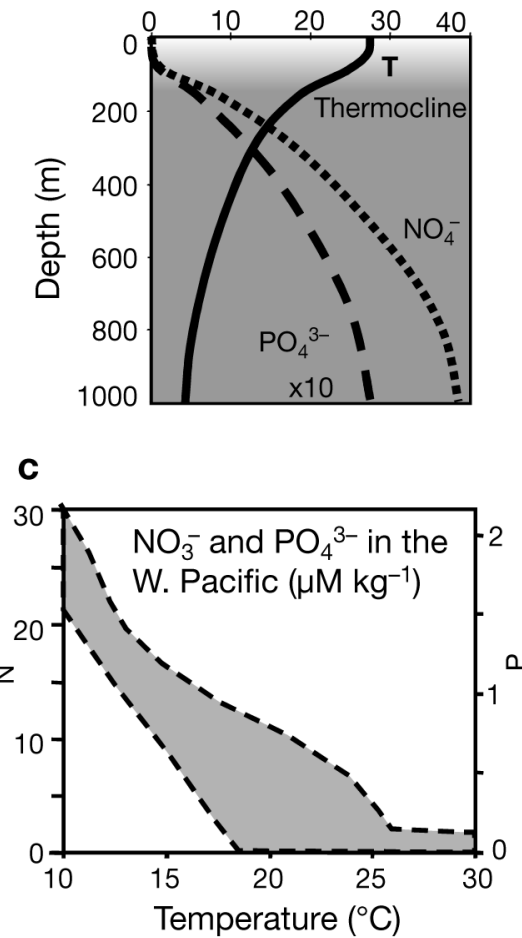

Fig. 3. Nutrient oceanography. (a) Mean annual phosphate concentrations $\left(\mu \mathrm{M} \mathrm{kg}^{-1}\right.$, solid lines) and $20^{\circ} \mathrm{C}$ isotherms $(\mathrm{dotted}$

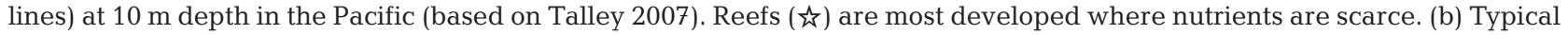
vertical profiles of nitrate, phosphate, and temperature in the western Pacific. (c) Envelope of typical nitrate and phosphate concentrations plotted against temperature for the western Pacific 

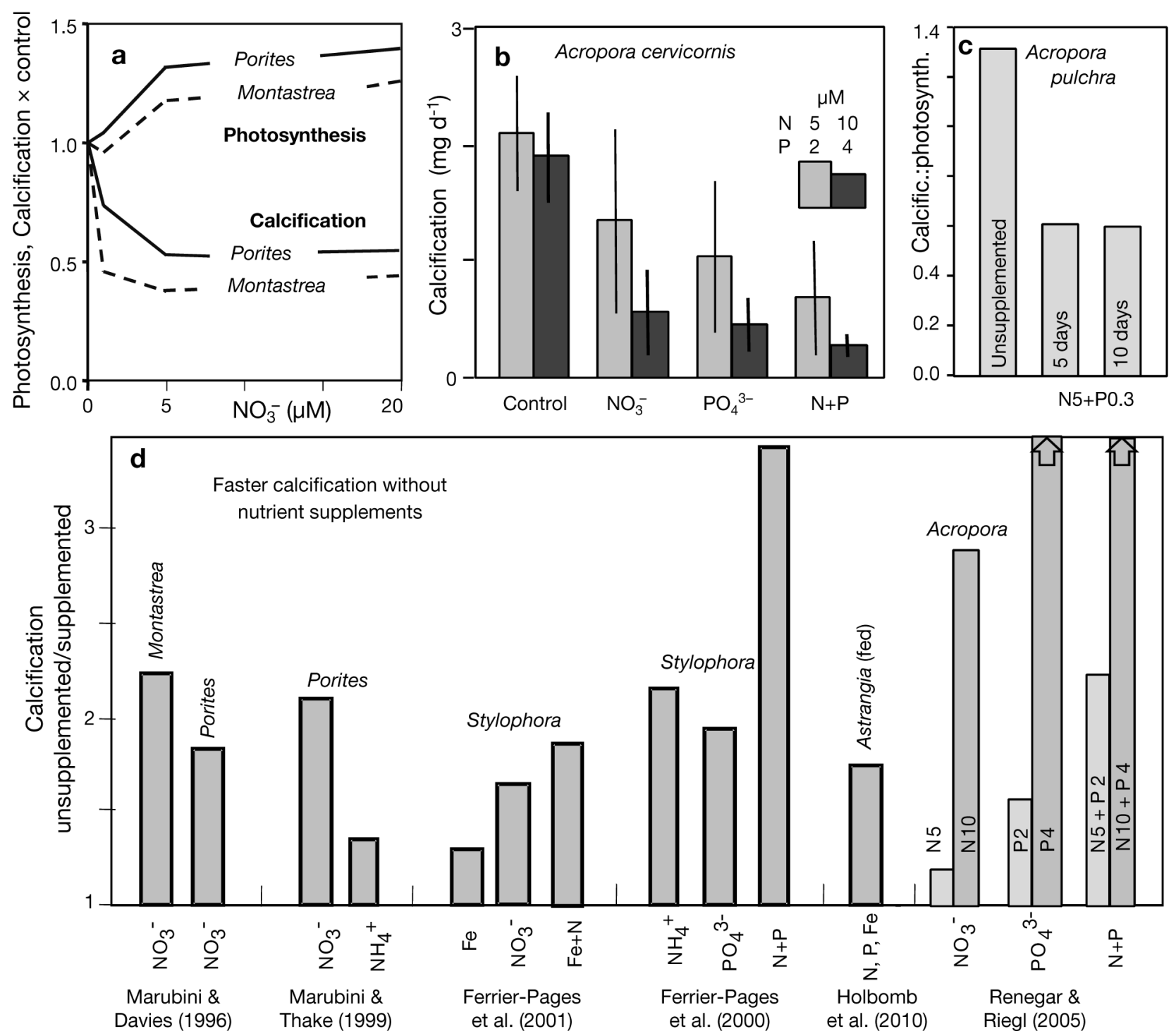

Fig. 4. Faster calcification during nutrient scarcity. (a) Nitrate supplementation stimulated photosynthesis but inhibited calcification in an experiment by Marubini \& Davies (1996). (b) N or P supplementation suppresses calcification in Acropora (Renegar \& Riegl 2005). (c) N+P supplementation (5 $\mu \mathrm{M}$ nitrate and $0.3 \mu \mathrm{M}$ phosphate) reduces the ratio of calcification to photosynthesis in Acropora (Tanaka et al. 2007). (d) Faster calcification without nutrient supplements (after several authors)

et al. 1994). Land plants and their symbiotic fungi often calcify in nutrient-poor alkaline soils (Jaillard et al. 1991, Khan 1995). Calcium carbonates and oxalates sometimes completely fill the vacuoles of root cortical cells, close to the sub-apical region of proton export and absorptive root hairs (Fig. 5a).

The physiology linking proton export to nutrient uptake has been most studied in land plants. Proton secretion leaches nutrients from the soil, and strengthens the cell membrane electrical gradient. That drives the electrophoretic uptake of cations, including $\mathrm{Fe}^{2+}$ and $\mathrm{NH}_{4}{ }^{+}$. $\mathrm{NO}_{3}{ }^{-}$and $\mathrm{PO}_{4}{ }^{3-}$ may be taken up in $\left(\mathrm{nH}^{+}\right.$, anion) combinations (Sakano 1990, Ull- rich \& Novacky 1990, Mistrik \& Ullrich 1996, Blatt et al. 1997, Wollenweber 1997, Zvyagilskaya et al. 2001). Lowering external $\mathrm{pH}$ by 1 unit theoretically improves the thermodynamics of $\mathrm{NO}_{3}{ }^{-}$and $\mathrm{PO}_{4}{ }^{3-}$ uptake at least 10-fold (Figs. 5b,c). Fig. 1 applies this idea to corals.

Algal toxins may speed coral calcification during nutrient shortages. Nutrient shortages freeze zooxanthellae in the G1 phase of the cell cycle (Muscatine et al. 1989, Muller-Parker et al. 1996, Smith \& Muscatine 1999, Wang et al. 2008; Fig. 6a), where dinoflagellates are often most toxic (Pan et al. 1999, Taroncher-Oldenburg et al. 1999, Guisande et al. 

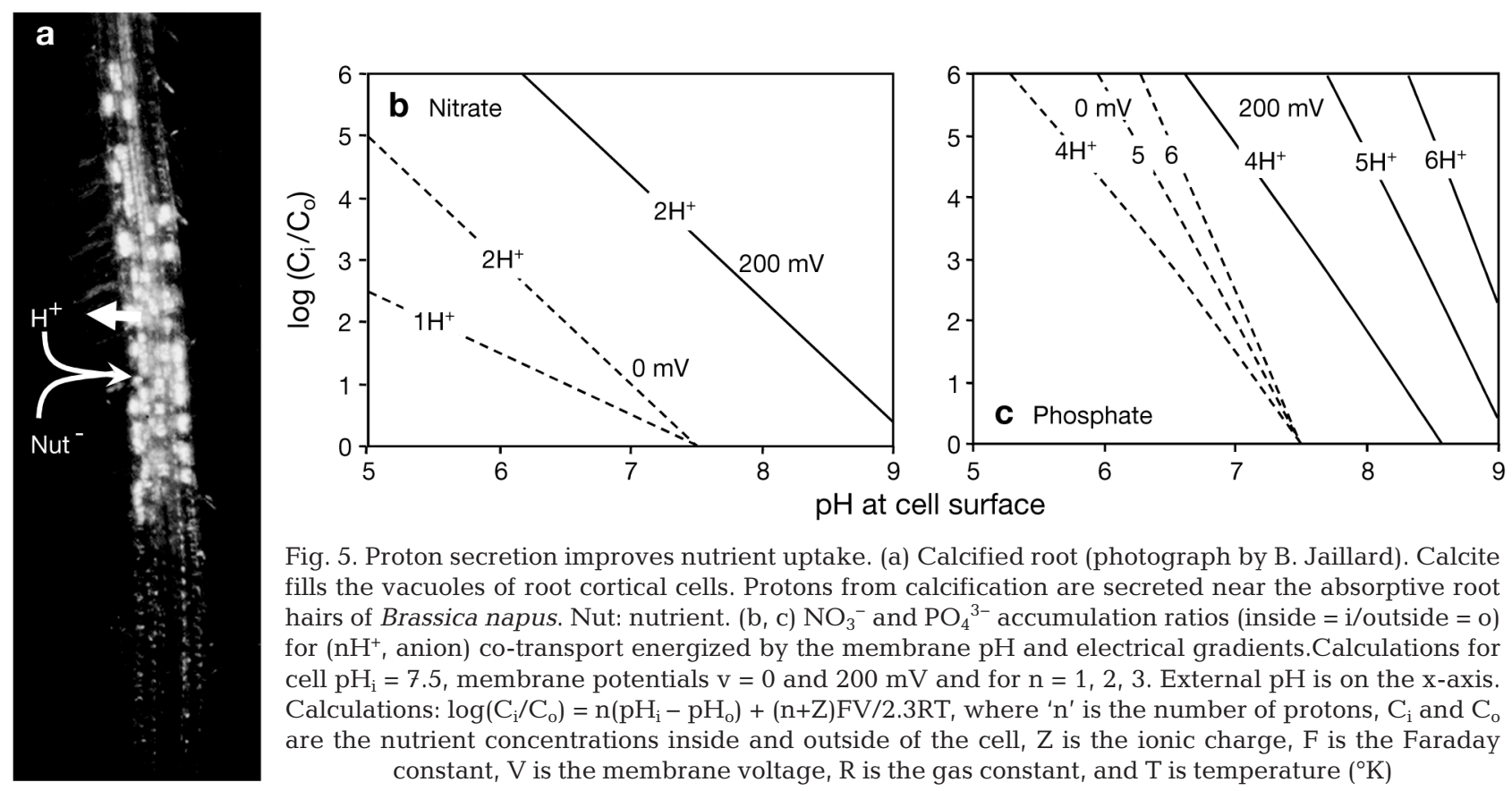

Fig. 5. Proton secretion improves nutrient uptake. (a) Calcified root (photograph by B. Jaillard). Calcite fills the vacuoles of root cortical cells. Protons from calcification are secreted near the absorptive root hairs of Brassica napus. Nut: nutrient. $(\mathrm{b}, \mathrm{c}) \mathrm{NO}_{3}{ }^{-}$and $\mathrm{PO}_{4}{ }^{3-}$ accumulation ratios (inside $=\mathrm{i} /$ outside $=0$ ) for $\left(\mathrm{nH}^{+}\right.$, anion) co-transport energized by the membrane $\mathrm{pH}$ and electrical gradients. Calculations for cell $\mathrm{pH}_{\mathrm{i}}=7.5$, membrane potentials $\mathrm{v}=0$ and $200 \mathrm{mV}$ and for $\mathrm{n}=1,2,3$. External $\mathrm{pH}$ is on the $\mathrm{x}$-axis. Calculations: $\log \left(\mathrm{C}_{\mathrm{i}} / \mathrm{C}_{0}\right)=\mathrm{n}\left(\mathrm{pH}_{\mathrm{i}}-\mathrm{pH}_{\mathrm{o}}\right)+(\mathrm{n}+\mathrm{Z}) \mathrm{FV} / 2.3 \mathrm{RT}$, where ' $\mathrm{n}$ ' is the number of protons, $\mathrm{C}_{\mathrm{i}}$ and $\mathrm{C}_{0}$ are the nutrient concentrations inside and outside of the cell, $\mathrm{Z}$ is the ionic charge, $\mathrm{F}$ is the Faraday constant, $\mathrm{V}$ is the membrane voltage, $\mathrm{R}$ is the gas constant, and $\mathrm{T}$ is temperature $\left({ }^{\circ} \mathrm{K}\right)$

2002, Paz et al. 2004, Varkitzi et al. 2010). When cultures of Gambierdiscus (Chinain et al. 2010) and Ostreposis (Guerrini et al. 2010) transition from exponential growth to a nutrient-limited stationary phase, the polyketides maitotoxin, ovatoxin, and a putative palytoxin approximately double.

\section{ALGAL EXIT}

Departing zooxanthellae likely obtain nutrients from the host coral. Zooxanthellae become more mitotic and progress faster through the cell cycle in heat-stressed corals, and after release from the coral (Baghdasarian \& Muscatine 2000, Strychar et al. 2005; Fig. 6c-e). Warm seawater is generally nutrient depleted, so the nutrients needed to complete G1 phase and enter mitosis probably come from the host coral. Zooxanthellae also hyper-accumulate $\mathrm{NH}_{4}{ }^{+}$ from corals injured by Vibrio infections (Toren et al. 1998, Banin et al. 2001), and may similarly absorb nutrients from necrotic or apoptotic coral cells (Fig. 6f).

Several factors favor departure of nutrient-starved algae: they cannot easily reproduce in the coral (Fig. 6a), they can take coral nutrients as they leave, and they will likely die if they remain inside a bleaching coral (Dunn et al. 2004). The coral may also evict the algae, if they become too toxic, and mainly produce lipids (Muller-Parker et al. 1996).
Algal $\mathrm{Ca}^{2+}$ channel openers likely facilitate algal exit. Zooxanthellae sometimes depart within intact sloughed endodermal cells (Gates et al. 1992, Smith \& Muscatine 1999). Cell-cell adhesion depends on Velcro-like cadherin molecules, whose intracellular anchors detach when cell $\mathrm{Ca}^{2+}$ rises (Ito et al. 1999, Marambaud et al. 2002). $\mathrm{Ca}^{2+}$ also regulates exocytosis and apoptosis (Demaurex \& Distelhorst 2003, McMahon \& Gallop 2005, Harr \& Distelhorst 2010). Gene expression in heat-stressed corals suggests disrupted $\mathrm{Ca}^{2+}$ control, leading to cytoskeletal failure and loss of cell adhesion (DeSalvo et al. 2008). $\mathrm{Ca}^{2+}$ influxes also trigger egress in apicomplexan parasites, a sister group to the dinoflagellates (Farrell et al. 2012).

\section{CORAL BLEACHING}

Coral bleaching resembles algal dispersal in terms of its association with warm, nutrient-deficient waters, and symptoms like host cell apoptosis and sloughing (Weis 2008, Lesser 2011). Toxin-induced ion leakage across electron transport membranes and host immunological responses may increase the production of ROS and NO. Corals may suppress algal populations (Falkowski et al. 1993) to limit such pathology. Symbiotic zooxanthellae can nevertheless double in $\sim 1$ wk when nutrients are plentiful (Smith \& Muscatine 1999, Tanaka et al. 2007; Fig. 6a), and 

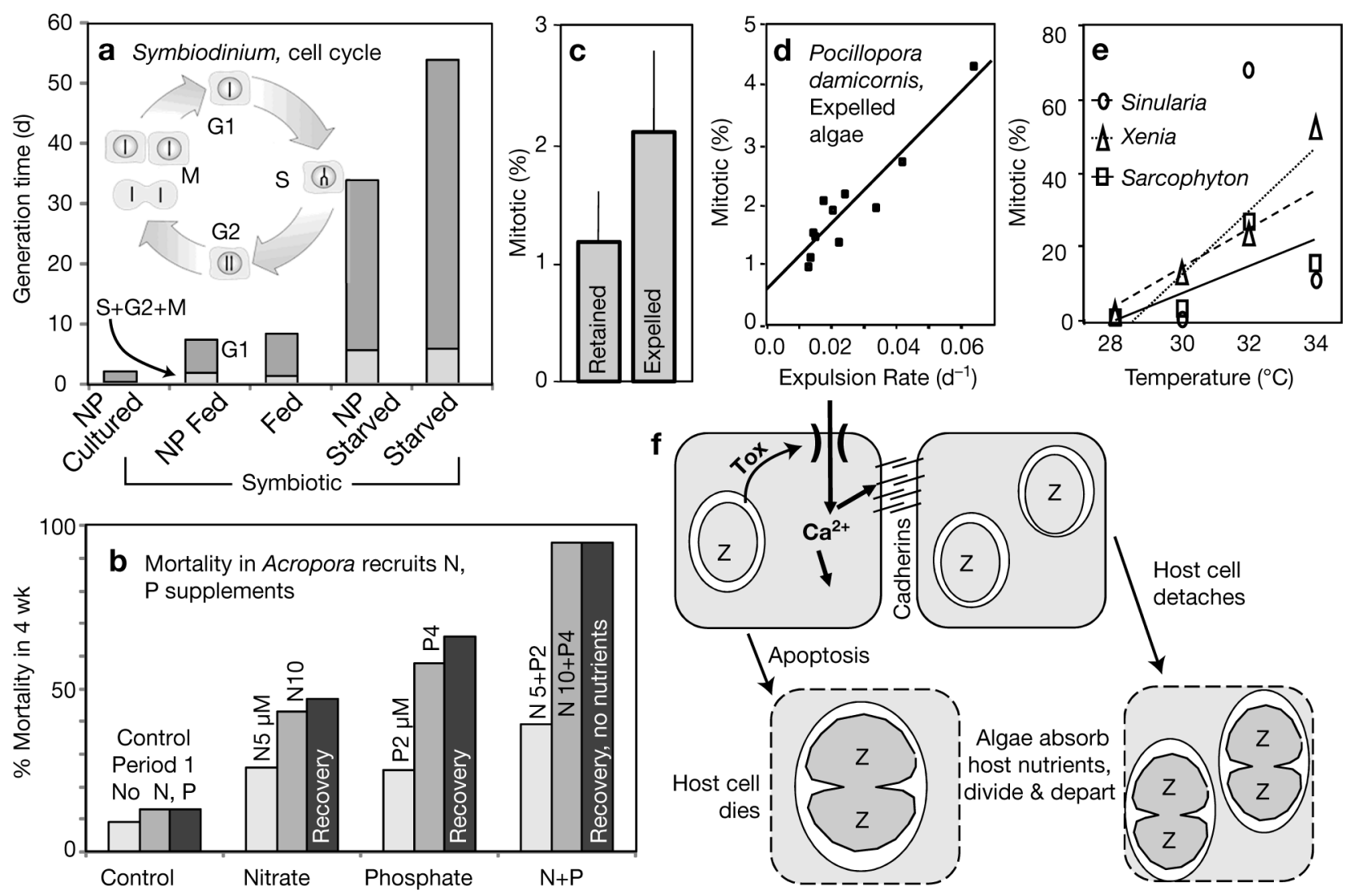

Fig. 6. Zooxanthellae life cycle. (a) Nutrient shortages prolong the G1 phase of the cell cycle (Smith \& Muscatine 1999). (b) Nutrient supplements increase mortality in Acropora recruits (Renegar \& Riegl 2005). (c, d) Expelled zooxanthellae are more mitotic (Baghdasarian \& Muscatine 2000). (e) Zooxanthellae are more mitotic during bleaching at high temperatures (Strychar et al. 2005). (f) Two calcium-dependent mechanisms of algal release: apoptosis or sloughing of infected cells

coral mortality sometimes increases markedly (Renegar \& Riegl 2005; Fig. 6b).

Slow but steady nutrient supplies probably reduce algal population explosions and exoduses. The diverse coral communities of the Red Sea illustrate this scenario. Deep waters there contain relatively few nutrients, but vertical mixing is fast for a tropical sea, and continues even in summer (Jean-Baptiste et al. 2004). Except in phosphorus-polluted areas (Walker \& Ormond 1982), the corals seldom bleach (Karako-Lampert et al. 2004).

Nutrients are more abundant near the bottom of the euphotic zone, but low zooxanthellar densities there (McCloskey \& Muscatine 1984) may prevent toxin overload. Nutrients are more plentiful and variable near rivers and upwelling zones, and corals are correspondingly less diverse, and reefs less developed. Human fertilization of the oceans (Szmant 2002, Kim et al. 2011) raises similar issues. When nutrients disappear, the over-abundant algae may suddenly become more toxic and depart. Hence nutrient pollution may contribute to recent increases in coral bleaching.

\section{DISCUSSION}

It will take considerable research to establish how algal toxins affect symbiotic corals. Toxins must be isolated and characterized, and their abundances monitored with respect to zooxanthellae densities, nutrient levels, and algal cell cycles. Toxin effects on coral calcification, algal exit, cell sloughing, and apoptosis should be tested. Toxins may also affect physiologies not discussed here, like algal invasion of the coral, evading its immune system, and poisoning coral predators. Zooxanthellae furthermore produce several toxins beyond $\mathrm{Ca}^{2+}$ channel openers. Timescales also matter, since algal densities change, and their toxicities likely change even faster.

Most dinoflagellate toxins modulate membrane cation transport (Rein \& Borrone 1999, Murata \& Yasumoto 2000, Shimizu 2003). Saxitoxins block $\mathrm{Na}^{+}$ channels, brevetoxins and ciguatoxins open $\mathrm{Na}^{+}$ channels, yessotoxins promote $\mathrm{Ca}^{2+}$ influx, and okadaic acid inhibits enzymes that control $\mathrm{Ca}^{2+}$ transport. Large, potent toxins seem to focus on $\mathrm{Ca}^{2+}$ in- 
flux. Palytoxin admits various cations including $\mathrm{Ca}^{2+}$ into cells through the $\mathrm{Na}^{+} / \mathrm{K}^{+}$ATPase, ovatoxins may work similarly, and maitotoxin, zooxanthellatoxins, and symbiodinolide admit $\mathrm{Ca}^{2+}$. Why do dinoflagellates make such toxins?

Dinoflagellates maintain a permanent nuclear membrane. Their chromosomes appear condensed, but lack typical histones and nucleosome structure (Hackett et al. 2004, Costas \& Goyanes 2005). Divalent cations, mainly $\mathrm{Ca}^{2+}$ and $\mathrm{Mg}^{2+}$, largely balance the negative charges on the DNA (Sigee 1986, Levi-Setti et al. 2008). $\mathrm{Ca}^{2+}$ binds tightly and may condense and inactivate the DNA for mitosis, while monovalents reactivate it during G1. Toxins may facilitate this cation exchange, with $\mathrm{Ca}^{2+}$ channel openers possibly letting $\mathrm{Ca}^{2+}$ out of the nucleus during G1. Such a histone-free cationic switch on DNA conformation and activity has interesting implications to the origins of the eukaryotic cell cycle and cytosolic calcium signaling.

Zooxanthellae may have secondarily adapted their cell cycle controls to external uses. However, a symbiosis dependent on toxins naturally has rough spots. When nutrients become scarce, algal toxins may prod the coral to calcify faster. If ambient waters simply lack nutrients, the algae may injure their hosts, steal their nutrients, reproduce, and seek new hosts. The coral survives this stress at low algal densities, but the sudden exit of overpopulated algae endangers the coral. Abundant zooxanthellae, and abundant nutrients, are a mixed blessing.

Other algae sometimes show similar toxic behavior. The haptophyte Prymnesium also makes $\mathrm{Ca}^{2+}$ influx agonists (Igarashi et al. 1998, Murata \& Yasumoto 2000). Prymnesium becomes most toxic when nutrients are scarce (Johansson \& Granéli 1999, Granéli \& Johansson 2003). It then kills and eats organisms ranging from plankton to fish (Skovgaard \& Hansen 2003, Tillmann 2003). Nutrient shortages seemingly transform the protist from a plant to a predator. Related algae colonize calcareous foraminifera (Gast et al. 2000).

Corals calcify beyond their immediate skeletal needs. Ultimately, a few millimeters of coral tissue may sit atop several meters of vacant skeleton. This continuing calcification reflects a continuing need for protons. Symbiotic foraminifera, calcareous sponges, giant clams, and calcareous algae use calcification similarly. Over millions of years, they produce limestone reefs many kilometers thick. Reefs concentrate in the tropics because that is where nutrient acquisition demands special physiologies. Zooxanthellae may also be easier to control when nutrients are scarce.
Dinoflagellate toxins invite new perspectives on many issues: how zooxanthellae communicate with their hosts, why calcareous animals make good hosts, why symbiotic corals calcify fastest at low nutrient levels and at high temperatures, how reefs flourish amidst nutrient scarcity, why dinoflagellate symbioses and coral reefs concentrate in the tropics, why high temperatures encourage algal exit and coral bleaching, and why bleaching has recently increased. Toxins seem like odd agents for promoting symbioses, but it would be even more odd if such potent agents had no effect.

Acknowledgements. L. Muscatine blazed most of the trails that converge here, and B. Sweeney nurtured my interests in dinoflagellates. Both were wonderful hosts. V. Weis, B. Buddemeier, G. Muller-Parker, F. Marubini, K. Strychar, C. Ferrier-Pagès, D. Sigee, A. Cohen, D. Allemand, J. Erez, and others provided insight. B. Jaillard provided a photograph. C. Birkeland helped immensely with editing. This paper is dedicated to the Japanese chemists who so skillfully characterized Symbiodinium's toxins.

\section{LITERATURE CITED}

Al-Horani FA, Al-Moghrabi SM, de Beer D (2003a) The mechanism of calcification and its relation to photosynthesis and respiration in the scleractinian coral Galaxea fascicularis. Mar Biol 142:419-426

Al-Horani FA, Al-Moghrabi SM, de Beer D (2003b) Microsensor study of photosynthesis and calcification in the scleractinian coral, Galaxea fascicularis. J Exp Mar Biol Ecol 288:1-15

Aponte NE, Ballantine DL (2001) Depth distribution of algal species on the deep insular fore reef at Lee Stocking Island, Bahamas. Deep-Sea Res 48:2185-2194

Baghdasarian G, Muscatine L (2000) Preferential expulsion of dividing algal cells as a mechanism for regulating algal-cnidarian symbiosis. Biol Bull (Woods Hole) 199: 278-286

Banin E, Khare SK, Naider F, Rosenberg E (2001) Prolinerich peptide from the coral pathogen Vibrio shiloi that inhibits photosynthesis of zooxanthellae. Appl Environ Microbiol 67:1536-1541

- Bentov S, Brownlee C, Erez J (2009) The role of seawater endocytosis in the biomineralization process in calcareous foraminifera. Proc Natl Acad Sci USA 106: 21500-21504

Blatt MR, Maurousset L, Meharg AA (1997) High-affinity $\mathrm{NO}_{3}{ }^{-}-\mathrm{H}^{+}$cotransport in the fungus Neurospora: induction and control by $\mathrm{pH}$ and membrane voltage. J Membr Biol 160:59-76

Chinain M, Darius HT, Ung A, Cruchet P and others (2010) Growth and toxin production in the ciguatera-causing dinoflagellate Gambierdiscus polynesiensis (Dinophyceae) in culture. Toxicon 56:739-750

Clapham DE (2007) Calcium signaling. Cell 131:1047-1058 Cohen AL, McConnaughey TA (2003) Geochemical perspectives on coral mineralization. Rev Mineral Biochem 54:151-187 
Cooper TF, O'Leary RA, Lough JM (2012) Growth of Western Australian corals in the anthropocene. Science 335: 593-596

Costas E, Goyanes V (2005) Architecture and evolution of dinoflagellate chromosomes: an enigmatic origin. Cytogenet Genome Res 109:268-275

> Demaurex N, Distelhorst C (2003) Apoptosis - the calcium connection. Science 300:65-67

> Demes KW, Littler MM, Littler DS (2010) Comparative phosphate acquisition in giant-celled rhizophytic algae (Bryopsidales, Chlorophyta): fleshy vs. calcified forms. Aquat Bot 92:157-160

> DeSalvo MK, Voolstra CR, Sunagawa S, Schwarz JA and others (2008) Differential gene expression during thermal stress and bleaching in the Caribbean coral Montastraea faveolata. Mol Ecol 17:3952-3971

$>$ Dixon DA, Haynes DH (1989) $\mathrm{Ca}^{2+}$ pumping ATPase of cardiac sarcolemma is insensitive to membrane potential produced by $\mathrm{K}^{+}$and $\mathrm{Cl}^{-}$gradients but requires a source of counter-transportable $\mathrm{H}^{+}$. J Membr Biol 112:169-183

- Dunn SR, Thomason JC, Le Tissier MDA, Bythell JC (2004) Heat stress induces different forms of cell death in sea anemones and their endosymbiotic algae depending on temperature and duration. Cell Death Differ 11: 1213-1222

Falkowski PG, Dubinsky Z, Muscatine L, McCloskey L (1993) Population control in symbiotic corals. BioScience 43:606-611

Fang LS, Chen YW, Chen CS (1989) Why does the white tip of stony coral grow so fast without zooxanthellae? Mar Biol 103:359-363

Fang LS, Wang JT, Lin KL (1998) The subcellular mechanism of the release of zooxanthellae during coral bleaching. Proc Natl Sci Counc Repub China B Life Sci 22:150-158

Farrell A, Thirugnanam S, Lorestani A, Dvorin JD and others (2012) A DOC2 protein identified by mutational profiling is essential for apicomplexan parasite exotcytosis. Science 335:218-221

Ferrier-Pagès C, Gattuso JP, Dallot S, Jaubert J (2000) Effect of nutrient enrichment on growth and photosynthesis in the zooxanthellate coral Stylophora pistillata. Coral Reefs 19:103-113

Ferrier-Pagès C, Schoelzke V, Jaubert J, Muscatine L, Hoegh-Guldberg O (2001) Response of a scleractinian coral, Stylophora pistillata, to iron and nitrate enrichment. J Exp Mar Biol Ecol 259:249-261

Fukatsu T, Onodera KI, Ohta Y, Oba Y and others (2007) Zooxanthellamide $\mathrm{D}$, a polyhydroxy polyene amide from a marine dinoflagellate, and chemotaxonomic perspective of the Symbiodinium polyols. J Nat Prod 70:407-411

> Gast R, McDonnell TA, Caron DA (2000) srDNA-based taxonomic affinities of algal symbionts from a planktonic foraminifer and a solitary radiolarian. J Phycol 36: 172-177

Gates RD, Baghdasarian G, Muscatine L (1992) Temperature stress causes host cell detatchment in symbiotic cnidarians: implications for coral bleaching. Biol Bull (Woods Hole) 182:324-332

Gattuso JP, Allemand D, Frankignoulle M (1999) Photosynthesis and calcification at cellular, organismal, and community levels in coral reefs. Am Zool 39:160-183

Gattuso JP, Reynaud-Vaganay S, Furla P, Romaine-Lioud S, Jaubert J (2000) Calcification does not stimulate photosynthesis in the zooxanthellate scleractinian coral Stylophora pistillata. Limnol Oceanogr 45:246-250
Gladfelter E (1983) Circulation of fluids in the gastrovascular system of the reef coral Acropora cervicornis. Biol Bull (Woods Hole) 165:811-815

Granéli E, Johansson N (2003) Increase in the production of allelopathic substances by Prymnesium parvum cells grown under N- or P-deficient conditions. Harmful Algae 2:135-146

> Guerrini F, Pezzolesi L, Feller A, Riccardi M and others (2010) Comparative growth and toxin profile of cultured Ostreopsis ovata from the Tyrrhenian and Adriatic Seas. Toxicon 55:211-220

> Guisande C, Frangópulos M, Maneiro I, Vergara AR, Riveiro I (2002) Ecological advantages of toxin production by the dinoflagellate Alexandrium minutum under phosphorus limitation. Mar Ecol Prog Ser 225:169-176

Hackett JD, Anderson DM, Erdner DL, Bhattacharya D (2004) Dinoflagellates: a remarkable evolutionary experiment. Am J Bot 91:1523-1534

Harr MW, Distelhorst CW (2010) Apoptosis and autophagy: decoding calcium signals that mediate life or death. Cold Spring Harbor Perspect Biol 2:a005579

> Holcomb MC, McCorkle DC, Cohen AL (2010) Long-term effects of nutrient and $\mathrm{CO}_{2}$ enrichment on the temperate coral Astrangia poculata (Ellis and Solander 1786). J Exp Mar Biol Ecol 386:27-33

Igarashi T, Aritake S, Yasumoto T (1998) Biological activities of prymnesin-2 isolated from a red tide alga Prymnesium parvum. Nat Toxins 6:35-41

Ito K, Okomoto I, Araki N, Kawano Y and others (1999) Calcium influx triggers the sequential proteolysis of extracellular and cytoplasmic domains of E-cadherin, leading to loss of $\beta$-catenin from cell-cell contacts. Oncogene 18: 7080-7090

Jaillard B, Guyon A, Maurin AF (1991) Structure and composition of calcified roots, and their identification in calcareous soils. Geoderma 50:197-210

Jean-Baptiste P, Fourré E, Metzl N, Ternon JF, Poisson A (2004) Red Sea deep water circulation and ventilation rate deduced from the ${ }^{3} \mathrm{He}$ and ${ }^{14} \mathrm{C}$ tracer fields. J Mar Syst 48:37-50

Johansson N, Granéli E (1999) Influence of different nutrient conditions on cell density, chemical composition and toxicity of Prymnesium parvum (Haptophyta) in semi-continuous cultures. J Exp Mar Biol Ecol 239:243-258

> Karako-Lampert S, Katcoff DJ, Achituv Y, Dubinsky Z, Stambler N (2004) Do clades of symbiotic dinoflagellates in scleractinian corals of the Gulf of Eilat (Red Sea) differ from those of other coral reefs? J Exp Mar Biol Ecol 311: 301-314

Khan SR (1995) (ed) Calcium oxalate in biological systems. CRC Press, Boca Raton, FL

Kim TW, Lee K, Najjar RG, Jeong HD, Jeong HJ (2011) Increasing $\mathrm{N}$ abundance in the northwestern Pacific Ocean due to atmospheric nitrogen deposition. Science 334:505-509

> Kinsey DW, Davies PJ (1979) Effects of elevated nitrogen and phosphorus on coral reef growth. Limnol Oceanogr 24:935-940

Kita M, Ohishi N, Konishi K, Kondo M and others (2007) Symbiodinolide, a novel polyol macrolide that activates $\mathrm{N}$-type $\mathrm{Ca}^{2+}$ channel, from the symbiotic marine dinoflagellate Symbiodinium sp. Tetrahedron 63:6241-6251

Kita M, Ohno O, Han C, Uemura D (2010) Bioactive secondary metabolites from symbiotic marine dinoflagellates: symbiodinolide and durinskiols. Chem Rec 10:57-69 
LaJeunesse TC, Lambert G, Anderson RA, Coffroth MA, Galbraith DW (2005) Symbiodinium (Pyrrhophyta) genome sizes (DNA content) are smallest among dinoflagellates. J Phycol 41:880-886

Leggat W, Marendy EM, Baillie B, Whitney SM, Ludwig M, Badger MR, Yellowlees D (2002) Dinoflagellate symbioses: strategies and adaptations for the acquisition and fixation of inorganic carbon. Funct Plant Biol 29:309-322

Lesser MP (2011) Coral bleaching: causes and mechanisms. In: Dubinsky Z, Stambler N (eds) Coral reefs: an ecosystem in transition. Springer, Dordrecht, p 405-420

> Levi-Setti R, Gavrilov KL, Rizzo PJ (2008) Divalent cation distribution in dinoflagellate chromosomes imaged by high-resolution ion probe mass spectrometry. Eur J Cell Biol 87:963-976

- Marambaud P, Shioi J, Serban G, Georgakopoulos A and others (2002) A presenilin-1/ $\gamma$-secretase cleavage releases the E-cadherin intracellular domain and regulates disassembly of adherens junctions. EMBO J 21: 1948-1956

Marubini F, Davies PS (1996) Nitrate increases zooxanthellae population density and reduces skeletogenesis in corals. Mar Biol 127:319-328

Marubini F, Thake B (1999) Bicarbonate addition promotes coral growth. Limnol Oceanogr 44:716-720

McCloskey LR, Muscatine L (1984) Production and respiration in the Red Sea coral Stylophora pistillata as a function of depth. Proc R Soc Lond B Biol Sci 222:215-230

McConnaughey TA (1989) ${ }^{13} \mathrm{C}$ and ${ }^{18} \mathrm{O}$ isotope disequilibria in biological carbonates. 2. In vitro simulation of kinetic isotope effects. Geochim Cosmochim Acta 53:163-171

McConnaughey TA (2003) Sub-equilibrium oxygen-18 and carbon-13 levels in biological carbonates: carbonate and kinetic models. Coral Reefs 22:316-327

McConnaughey TA, LaBaugh JW, Rosenberry DO, Striegl RG, Reddy MM, Carter V (1994) Carbon budget for a groundwater-fed lake: calcification supports summer photosynthesis. Limnol Oceanogr 39:1319-1332

McMahon HT, Gallop JL (2005) Membrane curvature and mechanisms of dynamic cell remodelling. Nature 438: 590-596

McNeil BI, Matear RJ, Barnes DJ (2004) Coral reef calcification and climate change: the effect of ocean warming. Geophys Res Lett 31:L22309 doi:10.1029/2004GL021541

Mistrik I, Ullrich CI (1996) Mechanism of anion uptake in plant roots: quantitative evaluation of $\mathrm{H}^{+} / \mathrm{NO}_{3}{ }^{-}$and $\mathrm{H}^{+} / \mathrm{H}_{2} \mathrm{PO}_{4}^{-}$stoichiometries. Plant Physiol Biochem 34: 629-636

Muller-Parker G, Lee KW, Cook CB (1996) Changes in the ultrastructure of symbiotic zooxanthellae (Symbiodinium sp., Dinophyceae) in fed and starved sea anemones maintained under high and low light. J Phycol 32: 987-994

Murata M, Yasumoto T (2000) The structure, elucidation, and biological activities of high molecular weight algal toxins: maitotoxin, prymnesins, zooxanthellatoxins. Nat Prod Rep 17:293-314

> Muscatine L, Falkowski PG, Dubinsky Z, Cook PA, McCloskey LR (1989) The effect of external nutrient resources on the population dynamics of zooxanthellae on a coral reef. Proc R Soc Lond B Biol Sci 236:311-324

Nakamura H, Asari T, Ohizumi Y, Kobayashi J, Yamasu T, Murai A (1993) Isolation of zooxanthellatoxins, novel vasoconstrictive substances from the zooxanthella Symbiodinium sp. Toxicon 31:371-376
Niggli V, Sigel E, Carafoli E (1982) The purified Ca ${ }^{2+}$ pump of the human erythrocyte membrane catalyzes an electroneutral $\mathrm{Ca}^{2+} / 2 \mathrm{H}^{+}$exchange in reconstituted liposomal systems. J Biol Chem 257:2350-2356

> Onodera Ki, Nakamura H, Oba Y, Ohizumi Y, Ojika M (2005) Vasoconstrictive polyhydroxylated macrolides with the largest lactone ring size from a marine dinoflagellate of Symbiodinium. J Am Chem Soc 127: 10406-10411

> Paasche E, Brubak S (1994) Enhanced calcification in the coccolithophorid Emiliania huxleyi (Haptophyta) under phosphorus limitation. Phycologia 33:324-330

Pan Y, Cembella AD, Quilliam MA (1999) Cell cycle and toxin production in the benthic dinoflagellate Prorocentrum lima. Mar Biol 134:541-549

Paz B, Riobó P, Fernández LM, Fraga S, Franco JM (2004) Production and release of yessotoxins by the dinoflagellates Protoceratium reticulatum and Lingulodinium polyedrum in culture. Toxicon 44:251-258

> Rein KS, Borrone J (1999) Polyketides from dinoflagellates: origins, pharmacology and biosynthesis. Comp Biochem Physiol B Biochem Mol Biol 124:117-131

> Renegar DA, Riegl BM (2005) Effect of nutrient enrichment and elevated $\mathrm{CO}_{2}$ partial pressure on growth rate of Atlantic scleractinian coral Acropora cervicornis. Mar Ecol Prog Ser 293:69-76

> Ries JB (2011) A physicochemical framework for interpreting the biological calcification response to $\mathrm{CO}_{2}$-induced ocean acidification. Geochim Cosmochim Acta 75: 4053-4064

Sakano K (1990) Proton/phosphate stoichiometry in uptake of inorganic phosphate by cultured cells of Catharanthus roseus (L.) G. Don. Plant Physiol (Rockv) 93:479-483

Sawyer SJ, Muscatine L (2001) Cellular mechanisms underlying temperature-induced bleaching in the tropical sea anemone Aiptasia pulchella. J Exp Biol 204:3443-3456

Shimizu Y (2003) Microalgal metabolites. Curr Opin Microbiol 6:236-243

Sigee DC (1986) The dinoflagellate chromosome. Adv Bot Res 12:205-264

Silverman J, Lazar B, Erez J (2006) Community metabolism of a coral reef exposed to naturally varying dissolved inorganic nutrient loads. Biogeochemistry 84:67-82

Skovgaard A, Hansen PJ (2003) Food uptake in the harmful alga Prymnesium parvum mediated by excreted toxins. Limnol Oceanogr 48:1161-1166

Smith GJ, Muscatine L (1999) Cell cycle of symbiotic dinoflagellates: variation in G1 phase-duration with anemone nutritional status and macronutrient supply in the Aiptasia pulchella-Symbiodinium pulchrorum symbiosis. Mar Biol 134:405-418

> Strychar KB, Coatesa M, Sammarco PW, Pivab TJ, Scotta PT (2005) Loss of Symbiodinium from bleached soft corals Sarcophyton ehrenbergi, Sinularia sp. and Xenia sp. J Exp Mar Biol Ecol 320:159-177

> Szmant A (2002) Nutrient enrichment on coral reefs: Is it a major cause of coral reef decline? Estuaries 25:743-766

Talley LD (2007) Hydrographic atlas of the World Ocean Circulation Experiment (WOCE), Vol 2: Pacific Ocean. In: Sparrow M, Chapman P, Gould J (eds) International WOCE Project Office, Southampton

Tambutté E, Tambutté S, Segonds N, Zoccola D, Venn A, Erez J, Allemand D (2012) Calcein labeling and electrophysiology; insights into coral tissue permeability and calcification. Proc R Soc Lond B Biol Sci 279:19-27 
Tanaka Y, Miyajima T, Kioke I, Hayashibara T, Ogawa H (2007) Imbalanced coral growth between organic tissue and carbonate skeleton caused by nutrient enrichment. Limnol Oceanogr 52:1139-1146

Taroncher-Oldenburg G, Kulis DM, Anderson DM (1999) Coupling of saxitoxin biosynthesis to the G1 phase of the cell cycle in the dinoflagellate Alexandrium fundyense: temperature and nutrient effects. Nat Toxins 7: 207-219

Tillmann U (2003) Kill and eat your predator: a winning strategy of the planktonic flagellate Prymnesium parvum. Aquat Microb Ecol 32:73-84

Toren A, Landau L, Kushmaru Y, Loya Y, Rosenberg E (1998) Effect of temperature on adhesion of Vibrio strain AK-1 to Oculina patagonica and on coral bleaching. Appl Environ Microbiol 64:1379-1384

Ullrich CI, Novacky AJ (1990) Extra- and intracellular pH and membrane potential changes induced by $\mathrm{K}^{+}, \mathrm{CI}^{-}$, $\mathrm{H}_{2} \mathrm{PO}_{4}{ }^{-}$, and $\mathrm{NO}_{3}{ }^{-}$uptake and fusicoccin in root hairs of Limnobium stoloniferum. Plant Physiol (Rockv) 94: 1561-1567

- Varkitzi I, Pagou K, Granéli E, Hatzianestis I and others (2010) Unbalanced N:P ratios and nutrient stress controlling growth and toxin production of the harmful dinoflagellate Prorocentrum lima (Ehrenberg) Dodge. Harmful Algae 9:304-311

Walker DI, Ormond RFG (1982) Coral death and phosphate pollution in Aqaba, Red Sea. Mar Pollut Bull 13:21-25

Editorial responsibility: Charles Birkeland,

Honolulu, Hawaii, USA
Wang LH, Liu YH, Ju YM, Hsiao YY, Fang LS, Chen CS (2008) Cell cycle propagation is driven by light-dark stimulation in a cultured symbiotic dinoflagellate isolated from corals. Coral Reefs 27:823-835

Weis VM (2008) Cellular mechanisms of cnidarian bleaching: stress causes collapse of symbiosis. J Exp Biol 211: 3059-3066

- Wollenweber B (1997) A sensitive computer-controlled pHstat system allows the study of net $\mathrm{H}^{+}$fluxes related to nitrogen uptake of intact plants in situ. Plant Cell Environ 20:400-408

> Yuyama I, Watanabe T, Takei Y (2011) Profiling differential gene expression of symbiotic and aposymbiotic corals using a high coverage gene expression profiling (HiCEP) analysis. Mar Biotechnol 13:32-40

Zoccola D, Tambutté E, Sénégas-Balas F, Michiels JF, Failla JP, Jaubert J, Allemand D (1999) Cloning of a calcium channel $\alpha 1$ subunit from the reef-building coral, Stylophora pistillata. Gene 227:157-167

Zoccola D, Tambutté E, Kulhanek E, Puverel S and others (2004) Molecular cloning and localization of a PMCA Ptype calcium ATPase from Stylophora pistillata. Biochim Biophys Acta 1663:117-126

Zvyagilskaya R, Parchomenko O, Abramova N, Allard P (2001) Proton- and sodium-coupled phosphate transport systems and energy status of Yarrowia lipolytica cells grown in acidic and alkaline conditions. J Membr Biol 183:39-50

Submitted: January 26, 2012; Accepted: April 23, 2012

Proofs received from author(s): July 5, 2012 